\title{
The Influence of Price and Family Welfare on the Practice of Buying and Selling Palm Oil in Islam (Case Study) in Sidomulyo Village, Muara Lakit District, Musi Rawas Regency
}

\author{
Nova Yanti Maleha ${ }^{1}$, Bagus Setiawan ${ }^{2}$,Chandra Satria ${ }^{3}$, Intan Junitasari ${ }^{4}$ \\ \{nova@stebisigm.ac.id ${ }^{1}$, bagus@stebisigm.ac.id ${ }^{2}$, chandras@ stebisigm.ac.id $^{3}$, \\ IntanJunitasari@student.stebisigm.ac.id $\left.{ }^{4}\right\}$
}

Sekolah Tinggi Ekonomi dan Bisnis Syariah Indo Global Mandiri (STEBIS IGM), Palembang, Indonesia ${ }^{1}$ Sekolah Tinggi Ekonomi dan Bisnis Syariah Indo Global Mandiri (STEBIS IGM), Palembang, Indonesia², Sekolah Tinggi Ekonomi dan Bisnis Syariah Indo Global Mandiri (STEBIS IGM), Palembang, Indonesia ${ }^{3}$, Sekolah Tinggi Ekonomi dan Bisnis Syariah Indo Global Mandiri (STEBIS IGM), Palembang, Indonesia ${ }^{4}$,

\begin{abstract}
Abtract. Most of the people of Sidomulyo's livelihood are farmers. Many farmers sell their crops to middlemen, because the yields obtained do not cover the requirements to sell directly to the factory and the results obtained are not comparable to a fairly long journey [1]. In line with these problems, this study aims to determine the Islamic law review of the system of implementing the practice of middlemen in the village. This research uses quantitative data, using field studies through interviews, distributing questionnaires and documentation as well as literature related to the problem under study. The results of this study indicate that the price and welfare of the community both partially and simultaneously have an effect on the practice of buying and selling oil palm in Sidomulyo Village, Muara Lakit District, Musi Rawas Regency.
\end{abstract}

Keywords: Price, Welfare, Ijon Buying and Selling Practices

\section{Intoduction}

Islam is a perfect religion, in which Islam regulates all aspects of human life, both from faith, morals, worship and muamalah. In everyday life muamalah is often done to support human life and welfare. Welfare in a modern concept is a condition in which a person can meet basic needs, be it food, clothing, shelter, education, clothing, and work that can support a better life.

According to Sudarsono, people's welfare is a good economic condition because the rules in the economy governing the activities of all parties and the distribution of community income as a result of these economic activities. In all analyzes, welfare is assumed to be something that is directly related to household income and consumption. The focus is on the level of consumption, including health insurance, housing, direct financial assistance, education and other areas of social welfare. In Islamic economics, the success of a branch of science and policy is the extent to which it contributes directly or indirectly to the realization of human welfare, this is clearly the goal of Maqashid al-syari'ah.

Sidomulyo Village is one of the agricultural villages, which means the village with the largest livelihood for the population is in agriculture and plantations. In Sidomulyo village, there are many oil palm and rubber plantations which are the main source of livelihood for the population compared to other jobs.

The level of family welfare in Sidomulyo Village is greatly influenced by the oil palm plantation sector, because almost all residents meet their daily needs from the oil palm harvest. Almost every road or yard behind the house or around the house of the residents must plant or find oil palm trees. Here it proves that oil palm has a very high influence on family welfare. In Sidomulyo Village, there is one oil palm company (factory), namely PT PP Lonsum Sumatera Tbk, where the buying and selling price of palm oil is based on the price applied by the factory [2]. If the factory sets the price per kilogram of palm oil, it is $\mathrm{Rp} .1,450,-/ \mathrm{Kg}$, then the sale and purchase price of palm oil which middlemen give to residents ranges from Rp. 1,100, - / Kg to Rp. $1,150,-$ / Kg. 
Based on the facts that the researchers found in the field, the way oil palm middlemen dominate the market is by providing loans of money or goods to the community with an agreement to be paid with oil palm or in installments for each sale of palm oil. Regardless of the value of the community loan, it is still agreed by the oil palm middlemen by seeing how often the community sells their crops to the middlemen. Oil palm middlemen do not charge interest on the debt / loan and do not provide a deadline for repayment. Each time the sale, the amount owed is reduced according to the agreement between the two parties. Because they are in debt, the community is tied to the middlemen, and they are reluctant to sell the palm oil to other middlemen [3] In addition to the facts in daily life observed by the author, if the price of palm oil is high, the practice of buying and selling palm oil is also high and people's consumption tends to increase than usual, and vice versa if the price of palm oil decreases, the practice of buying and selling palm oil will also decrease and the community tends to suppress it. the cost of consumption is as economical as possible.

\section{Literature Review}

\subsection{Understanding of Price}

According to the large Indonesian dictionary the meaning of price is the value of goods that are determined or represented by money, it can also be interpreted as an amount of money or other means of exchange of value, which must be paid for products or services, at a certain time and in certain markets [4]. Meanwhile, according to the terminology defines as follows:

a. According to Philip Kotler Price is one element of the marketing mix that generates income; other elements generate costs. Price is the most adaptable element of the marketing mix; product features, channels, even promotions take more time. Price also communicates the company's intended value position to the market regarding its products and brands [5].

b. Prof. DR. H. Buchari Alma said that in economic theory, the notions of price, value and utility are the most related concepts. What is meant by utility is an attribute attached to an item that enables the item to fulfill its needs, wants and satisfy consumers. So the price (price) is the value of an item expressed in money [6].

\subsection{Welfare According to Islam}

Welfare according to Islam includes material and non-material welfare. Islam teaches that property is not the only indicator of welfare because basically property is only a tool used for the purpose of worshiping Allah SWT. Allah has spread sustenance for humans on earth and in the sky, to obtain this sustenance, humans must certainly try. One form of business in obtaining sustenance is by working. By working, humans will get a reward in the form of a salary or income. Allah SWT does not need any sustenance from humans, but it is Allah SWT who provides sustenance to humans. Allah explains this in Sura Adz-Zariyat verses 56-58.

\subsection{Understanding Buying and Selling}

According to the large Indonesian dictionary the definition of sale and purchase is a mutually binding agreement between the seller, namely the party who delivers the goods, and the buyer as the party who pays the price of the goods sold [4]. The definition of buying and selling according to the basic principles of Islamic economics is a contract, like any other civil contract, which is made based on a statement (ijab) and a request (qabul) that is clearly stated either verbally or otherwise which has the same meaning. The statement can be made in person or by letter or news. The sale and purchase contract, according to the Qur'an, should be written, whether small or large, along with the terms and witnesses [7].

The definition of buying and selling or Bay'u is an activity of exchanging goods with other goods in a certain way either using a contract or not using a contract [8]. In essence, between the seller and the buyer each knows that the sale and purchase transaction has taken place perfectly.

According to Sayyid Sabiq, the definition of buying and selling is the exchange of property for assets on the basis of giving up or transferring property in a justified exchange. According to the Hanagiyah Ulama, buying and selling is the exchange of property for assets in certain ways or exchanging something desired for something equivalent in certain useful ways. According to Ibn 
Qudamah Buying and Selling is exchanging property with assets in the form of transfer of ownership and ownership [9].

\subsection{Pillars of Buying and Selling Islam}

The pillars of buying and selling that must be fulfilled include:

a. There are people who have contract or al-muta'aqidain (sellers and buyers).

b. The existence of shighat (pronunciation of consent and kabul).

c. There are items purchased.

d. There is a replacement exchange rate for goods [9].

\subsection{Law Underlying Islamic Buying and Selling}

In Islam, the laws that underlie the practice of buying and selling are verses of the Al-Qur'an and the Hadith of the Prophet Muhammad. Islam allows its people to do business. As has been explained in Surah Al-Baqarah verse 198. It has also been explained in Al-Baqarah verse 275.

\section{Methods}

\subsection{Research sites}

This research was conducted at the Sale and Purchase of Mr Alam Sari's Palm Oil in the village of Sidomulyo, Muara Lakit Subdistrict, Musi Rawas Regency. This is a private micro, small, medium enterprise (MSME) owned by Mr. Alam as a palm oil middleman in Sidomulyo Village.

\subsection{Types of research}

The type of data used in this research is quantitative data, quantitative data is a method for testing certain theories by examining the relationship between variables [10].

\subsection{Data source}

In this study, there are two sources of data used, namely primary and secondary. Primary data is the main data obtained by using field studies interviewing and distributing questionnaires to respondents, namely middlemen and palm oil seller communities in Sidomulyo village. Meanwhile, secondary data is taken from documentation of prices and recaps recorded by middlemen as well as palm prices recorded by palm oil mills in Sidomulyo village and literature related to the problems studied, such as literature books that are related to the issues discussed.

\subsection{Population and Sample}

Population is the subject of research. Population is used to mention all elements / members of an area that is the target of research or is the whole (universe) of the research object. The sample is part or representative of the research object. The population in this study were middlemen and small communities who have oil palm plantations in the house and sell their crops to middlemen. The sample in this study consisted of 88 heads of families/residents who owned oil palm plantations in the house and sold their crops to middlemen.

\subsection{Data collection technique}

The data collection technique in this study was carried out by using a questionnaire distribution technique, the research was to distribute a list of questions to oil palm farmers or residents who carry out the practice of buying and selling oil in Sidomulyo Village, Muara Lakit District, Musi Rawas Regency.

\subsection{Analysis Technique}

The data that has been collected is then analyzed quantitatively, where quantitative is a method for testing certain theories by examining the relationship between variables. By using correlational studies, survey research and data quality testing, classical assumption tests, multiple linear regression and hypothesis testing carried out using the SPSS (Statistical Package for Social Science) computer program 22. 


\section{Results And Discussion}

Palm Oil Trading Practices System Applicable to Middlemen in Sidomulyo Village, Muara Lakit District, Musi Rawas Regency.

Based on the results of observations, interviews and questionnaires that the system of oil palm buying and selling in Sidomulyo Village is good and correct, in accordance with Islamic requirements and is able to benefit between middlemen and oil palm farmers and does not harm either party.

The method of middlemen who opens interest-free lending services by paying when oil palm farmers sell their crops to middlemen is allowed in Islam, because in Islam it is permissible for debt and credit on the basis of helping. As has been explained in Surah Al-Baqarah verse 245 as well as the verse which explains that debt payments must be hastened, namely Surat Al-Baqarah verse 282. From the letter above the debt and credit is allowed when in an urgent situation and middlemen help without regarding usury And an agreement has been made. which has been agreed between middlemen and oil palm farmers, so that no one feels disadvantaged in it.

From the author's observations and interviews that have been poured into the questionnaire questions which have been tested for validity and reliability, almost all samples agree with the author's question which contains the system of oil palm buying and selling practice in Sidomulyo Village is good and correct.

\subsection{The Effect of Price ( $\left.X_{1}\right)$ on Palm Oil Buying and Selling Practices (Y) in Sidomulyo Village, Muara Lakit District, Musi Rawas Regency.}

Based on the results of hypothesis testing, it is found that the price variable (X1) has a t-count value greater than $t$ table $(6.441>1.98827)$ and a significant level less than $0.05(0.00<0.05)$. This shows that the price variable (X1) partially has a significant relationship with palm oil trading practices (Y). So, $\mathrm{H}_{\mathrm{a}}{ }^{1}$ is accepted and $\mathrm{H}_{0}$ is rejected. From the research results, it can be concluded that the price of palm oil has a positive and significant effect on palm oil trading practices. Thus, the higher the price level for palm oil, the practice of buying and selling palm oil is also higher or increasing.

\subsection{The Effect of Family Welfare $\left(\mathrm{X}_{2}\right)$ on Palm Oil Buying and Selling Practices (Y) in Sidomulyo Village, Muara Lakit District, Musi Rawas Regency}

Based on the results of hypothesis testing, it is found that the Family Welfare variable $\left(\mathrm{X}_{2}\right)$ has a t-count value that is greater than the t-table value $(2.861>1.98827)$, and a significant level that is less than or equal to $0.05(0.05 \leq 0.05)$. This shows that the variable family welfare parisally has a significant effect on the practice of buying and selling oil palm. So, $\mathrm{H}_{\mathrm{a}}{ }^{1}$ is accepted and $\mathrm{H}_{0}$ is rejected. From the results of the study it can be concluded that family welfare has a positive and significant effect on the practice of buying and selling oil palm. Thus, the higher the welfare of the family, it will be marked by an increase in the practice of buying and selling oil palm.

\subsection{The Influence of Price $\left(X_{1}\right)$ and Family Welfare $\left(X_{2}\right)$ on Palm Oil Trading Practices in} Sidomulyo Village, Muara Lakit District, Musi Rawas Regency

The results of the study indicate that there is an effect of price and family welfare on the practice of buying and selling oil palm in Sidomulyo Village. This is evidenced by the statistical results of Fcount of 36.279 one unit and Ftable of 3.10 with a significant level of $0.000<0.05$. This shows that Fcount> Ftable (36.279> 3.10). This calculation shows that the variable price and family welfare have a simultaneous influence on the practice of buying and selling oil palm. The results of the $\mathrm{R}^{2}$ determination test in this study obtained a determination value of 0.448 one unit, meaning that the percentage of the contribution of the influence of price variables and family welfare on the practice of buying and selling palm oil was $44.8 \%$, while the remaining $55.2 \%$ was explained by other variables not included in the research model. this.

Based on the previous hypothesis testing, it can be seen that from the three significant variables, it turns out that the price variables and family welfare together have an influence on the 
practice of buying and selling oil palm in Sidomulyo Village, Muara Lakit District, Musi Rawas Regency.

\section{Conclusion}

Based on the results of research that has been conducted regarding the effect of price and family welfare on the practice of buying and selling oil palm in Sidomulyo Village, Muara Lakit District, Musi Rawas Regency, it can be concluded:

a. The practice of buying and selling carried out by middlemen is quite correct and good, this has been agreed upon by the respondent who filled out a questionnaire designed by the author and the middleman also opens money lending services for regular customers who sell their crops to the middlemen, this is permitted in Islam. as stated in Surah Al-Baqarah verses 245 and 282. Because it does not contain usury and aims to help fellow Muslims this is allowed.

b. The variable price of oil palm (X1) and family welfare (X2) together or simultaneously have a significant effect on the practice of buying and selling oil palm (Y). Shown by the results of the F test, the calculation results obtained Fcount> Ftable (36.279> 3.10) and a significant level less than $0.05(0.000<0.05)$. When the price of palm oil rises and the harvest increases, there is an increase in the practice of buying and selling palm oil and the welfare of the family increases because of the many expenses that are met.

\section{Reference}

[1] A. Savitri, "Jual beli kopi di desa Way Wakak Kecamatan Abung Barat Dalam Perspektif Ekonomi Islam," skripsi, vol. 101, p. 3, 2019.

[2] A. Sari, "Keterangan Pengepul Kelapa Sawit," Sidomulyo, 2020.

[3] A. Sari, "Cara Pengepul Mempertahankan Konsumennya," Sidomulyo, 2019.

[4] B. pengembang bahasa dan Pembukuan, "KBBI," Kementerian Pendidikan dan Kebudayaan Republik Indonesia, [Online]. Available: https://kbbi.kemdikbud.go.id/entri/jual beli. 2016.

[5] P. Kotler, "Prinsip-prinsip Pemasaran", 2016.

[6] H. M. Birusman Nuryadin, "Harga Dalam Perspektif Islam," Mazahib, vol. 4, no. 1, pp. 86-99, 2007.

[7] M. S. Chaudhry, "Sistem Ekonomi Prinsip Dasar Islam", Edisi pert. cetakan ke 3, 2016.

[5] Nurhayati and ali imran Sinaga, Fiqh dan ushul fiqh. 2018.

[8] Abdur rahman Ghazalyy, G. Ihsan, and S. Shidio, "Fiqh muamalat". 2015.

[9] J. Noor, "Metodologi Penelitian", Ke 6. Jakarta, 2016. 